\title{
Effects of Organizational Cynicism Occupational Commitment and Organizational Dissent on Knowledge Inertia
}

\author{
Doç. Dr. Mustafa ÖZGENEL* \\ İstanbul Sabahattin Zaim Üniversitesi, Eğitim Fakültesi, Temel Eğitim Bölümü, İstanbul / Türkiye, \\ mustafa.ozgenel@izu.edu.tr, ORCID: 0000-0002-7276-4865

\section{Dr. Öğr. Üyesi Mehmet ÇETIN} \\ İstanbul Sabahattin Zaim Üniversitesi, İşletme ve Yönetim Bilimleri Fakültesi, İşletme Bölümü, \\ İstanbul / Türkiye, mehmet.cetin@izu.edu.tr, ORCID: 0000-0001-9773-9714
}

\begin{abstract}
As adaptation, flexibility, change, responsiveness, and agility increasingly become inevitable components of success; knowledge inertia stands as one of the most essential obstacles for contemporary organizations. Given the nature of their mission, knowledge inertia is specifically crucial for the effectiveness of educational organizations, yet it remains as an understudied concept that necessitates further efforts. This paper contributes to our understanding on the antecedents and the underlying mechanisms on how these antecedents yield to knowledge inertia via an original research model. We ran our analysis on the data from a total of 440 teachers working in public schools. Correlation analysis and structural equation modeling was used for testing the links between variables. Results of the path analysis indicate a significant positive direct effect of organizational cynicism on knowledge inertia, and negative direct effects on occupational commitment and organizational dissent. Both
\end{abstract}

* Sorumlu Yazar. Tel: +90 2126928953

Makale Tarih Bilgisi. Gönderim: 19.06.2020, Kabûl: 12.12.2020, Erken Görünüm: 25.02.2021, Basım: Aralık, 2021

(C) 2021. Kalem Eğitim ve Sağlık Hizmetleri Vakfı. Bütün Hakları Saklıdır. ISSN: 2146-5606, e-ISSN: 2687-6574. 
occupational commitment and organizational dissent affect knowledge inertia negatively. Although a full mediation was not validated, findings of bootstrapping analysis indicated significant indirect effects of organizational cynicism on knowledge inertia through occupational commitment and organizational dissent. Keywords: Knowledge inertia; Organizational cynicism; Occupational commitment; Organizational dissent; Education management.

\section{Örgütsel Sinizmin Mesleki Bağlılığın ve Örgütsel Muhalefetin Bilgi Ataletine Etkileri}

\section{$\ddot{\mathbf{O z}}$}

Uyum, esneklik, değişim, duyarlılık ve çeviklik giderek artan bir şekilde başarının kaçınılmaz bileşenleri haline geldiği için; bilgi ataleti, çağdaş örgütlerin önündeki en önemli engellerden birini oluşturmaktadır. Misyonları göz önüne alındığında, bilgi ataleti eğitim kuruluşlarının etkinliği için daha da önemli olmakla birlikte, konu, üzerinde henüz yeterince çalışma yapılmamış ve daha fazla araştırma gerektiren bir yapıdır. $\mathrm{Bu}$ makale, bilgi ataletinin öncülleri ve bu öncüllerin hangi mekanizmalar aracılığı ile kavrama yol açtıkları hakkındaki bilgimize özgün bir araştırma modeli ile katkıda bulunmaktadır. Çalışmanın analizleri devlet okullarındaki 440 öğretmenden toplanan veriler üzerine yapılmıştır. Değişkenler arasındaki ilişkileri incelemek üzere korelasyon analizi ve yapısal eşitlik modeli kullanılmıştır. Yol analizi sonuçları, örgütsel sinizmin bilgi ataleti üzerinde anlamlı ve olumlu yönde doğrudan etkisinin olduğunu ve mesleki bağlılık ve örgütsel muhalefet üzerinde anlamlı ve olumsuz doğrudan etkileri olduğunu göstermektedir. Hem mesleki bağlılık hem de örgütsel muhalefet, bilgi ataletini olumsuz yönde etkilemektedir. Tam bir arabuluculuk doğrulanmamış olmasına rağmen, önyükleme analizinin bulguları, örgütsel sinizmin, mesleki bağlılık ve örgütsel muhalefet yoluyla bilgi ataleti üzerinde anlamlı dolaylı etkisinin olduğunu göstermektedir.

Anahtar Kelimeler: Bilgi ataleti; Örgütsel sinizm; Mesleki bağlılık; Örgütsel muhalefet; Eğitim yönetimi.

\section{Introduction}

Flexibility, agility and proactivity are very crucial for the survival of organizations in the volatile and complex environment of the contemporary business world. The constant change in technology, customer expectations, and information necessitate organizations to be organic and highly responsive to the dynamics in the internal and external environment. Only the 
organizations that can sense the need for change, initiate to take action and adapt to requirements provided by the change can succeed in today's highly demanding markets. As rapidly changing dynamics increasingly demand more proactivity and agility, organizations invest considerable efforts in coping with inertia and its possible causes. Accordingly, more scholars today recognize the need to investigate the concept and its antecedents.

The significance of knowledge inertia is more prominent in a school setting and education organizations since the content of the job is directly related to information and knowledge. Renewal of the methods and systems of teaching, updating the materials and contents with contemporary developments and technology is crucial for the outcome of teaching efforts and the total success of the educational organization. Cheng and Lin (2011) in their study conducted with school teachers demonstrated the association between teachers' knowledge inertia and school effectiveness and organizational learning.

Inertia, in general, manifests itself as favoring the usage of the status quo instead of initiation for new ideas and change. Hedberg and Wolff (2003) conceptualized organizational inertia under two dimensions, insight inertia and action inertia. Insight inertia stands for being unable to see, understand, or sense the need and nature of the change in the environment. Insight inertia causes organizations to fail to scan and evaluate the changing dynamics, so they do not perceive the need for change. On the other hand, action inertia refers to the state where organizations are too slow to take necessary actions and inflexible to adapt change. Similarly, Liao (2002) and Liao, Fei and Liu (2008) explained knowledge inertia in two components. Learning inertia refers to the inefficiency and reluctance to seek new sources of knowledge and learn new concepts, ideas, and methods. Experience inertia stands for a state where individuals are stuck with old methods and experiences and are passive to engage in new ones. Experience inertia can be conceptualized as resistance and unwillingness to search for or utilize new methods for solving problems, instead of using the old and already experienced ones.

Although inertia has been a popular and well-established concept in physics and organization theory, and variables that can be considered as antonyms of the concept such as innovation, creativity, agility or flexibility (Boyer and Robert, 2006) have been center of attention, knowledge inertia is a new and understudied concept that is not older than 2 decades. What we 
know so far on knowledge inertia is limited with few attempts to define, conceptualize and measure the construct followed by some quantitative relational research models. Liao (2002) and Liao, Fei and Liu (2008) attempted to define and set the structure of the term. Knowledge inertia was taken into research models with the organizational fit and organizational learning (Zhao, Wu and Wang, 2012) and innovation and commitment to learning (Liao, Fei and Liu, 2008). The scarcity of the studies addressing the antecedents of the knowledge inertia is even more notable. Although current dynamics emphasize the importance of the concept for organizational success, there are few studies addressing the antecedents of knowledge inertia and the mechanisms underlying in the links between the concept and its antecedents. (Gray, D'Alessandro, Johnson and Carter, 2017; Kafchehi, Zamani and Ebrahimabadi, 2012).

In this paper, we suggest organizational cynicism, occupational commitment, and organizational dissent as antecedents for knowledge inertia. Specifically, the study tests the mediation model where organizational cynicism increases organizational dissent through occupational commitment and organizational dissent. The research model of the study remains unique, as (to our knowledge) this is the first study that tests the mediating effects of occupational commitment and organizational dissent on the association between organizational cynicism and knowledge inertia. The study will further our understanding of the antecedents and possible mechanisms on how these antecedents link with knowledge inertia.

\section{Theoretical Background and Hypotheses Development Effects of Organizational Cynicism on Knowledge Inertia}

Organizational cynicism is a pessimistic and skeptical form of negative expectations and perceptions towards the organization where employees believe the organization will fail their expectations and engage in counterproductive behaviors with the anger and distrust they feel for the organization (Andersson, 1996; Andersson and Bateman, 1997). The concept has three dimensions. Cognitive cynicism manifests itself as negative thoughts and beliefs about the organization while affective cynicism is associated with negative emotions and feelings regarding the organization and last behavioral cynicism is about the actions such as complaining or rumoring about the organization (Dean, Brandes and Dharwadkar, 1998).

One central reason for knowledge inertia is this lack of willingness to 
change and self-initiating this burdensome process. Every form of change, even to a better state, is subject to resistance. Individuals will remain in hemostasis and need a strong motivation to bear with the burden the change brings. Stanley, Meyer and Topolnytsky (2005) associated cynicism positively with resistance to change. Likewise, it is logical to expect that individuals with higher levels of cynicism will find trying new methods, changing their routine and work habits and seeking for the better harder than the ones with lower levels of cynicism. Bernerth, Armenakis, Feild and Walker (2007)'s findings demonstrating a negative association between organizational cynicism and change commitment supports the above argument and our suggestion on the link between organizational cynicism and inertia. Change and breaking a routine comes with uncertainty. Individuals tend to avoid uncertainty because it creates stress. Scanning for new approaches, going out of the comfort zone and questioning the old, needs vigor, commitment, and tolerance for uncertainty. Without trust for organization's and people's good intentions levels of uncertainty and stress increase the energy, motivation, and commitment to change decrease.

In line with the classical Theory X and Y (McGregor, 1960), accomplishing the tasks to a level that is in line with the standards and what is acceptable can possibly be reached by people who have general disbelief for human nature and organizations to be selfish, dishonest and fake, but for going the extra mile, individuals need trust and dedication. Therefore, organizational cynicism is a critical obstacle to the way people try new things, invest efforts to learn and adopt new methods. Supportively, Andersson and Bateman (1997) underline the negative association between organizational citizenship behavior and organizational cynicism. Schilling and Kluge (2009) denote cynicism as a barrier to organizational learning.

Creativity and inertia may consider as enemies (Mokyr, 2000). Gong Cheung, Wang and Huang (2012) emphasize the importance of trust and information exchange for creativity. Cynicism manifests itself with low levels of trust and unwillingness to share information. Through definitions of creativity and inertia concepts, these findings are supportive for the negative link between cynicism and inertia. Supportively, Zhang, Sun, Zheng and Liu (2019) provide evidence for the association between organizational cynicism and creativity.

Autonomy and assertiveness may be listed as important components for 
creativity, agility and proactivity (Ekvall and Tångeberg-Andersson, 1986; Joo, Yang and McLean, 2014). Individuals lower on autonomy and assertiveness may cause and experience higher levels of inertia. Naus, Iterson and Roe (2007) have provided evidence for a negative association between cynicism and autonomy and assertiveness. Given the pattern of associations and past evidence we hypothesize the following:

Hypothesis 1: Organizational cynicism has a significant and positive effect on knowledge inertia.

\section{Effects of Occupational Commitment on Knowledge Inertia}

Occupational commitment can be defined as one's willingness to pursue and continue a career in that occupation sourcing from identification, involvement and a fit between the characteristics of the occupation and the individual's expectations and values (Blau, 1985; Meyer, Allen and Smith, 1993; May, Korczynski and Frenkel, 2002). Specifically, Lee, Carswell and Allen (2000, p.800) define the concept as the "psychological link between an individual and his/her occupation that is based on $n$ reaction to that occupation". In light of the given definitions, it may be conceptualized as a positive attitude towards one's occupation that prevents intention to quit or change the career path; still, there is support for the link may be enlarged to the feelings and intentions towards the organization (Chang, Chi and Miao, 2007).

Occupational commitment is built upon the same structure that Meyer and Allen's (1991) well known three-dimensional organizational commitment construct (Meyer, Allen and Smith, 1993). The only difference is that, the third dimension, continuance commitment is constructed as two separate factors named as continuance commitment and accumulated costs (Blau, 2003).

The majority of the studies addressing the links between employee commitment and organizational variables focus on organizational commitment. The scarcity of studies on occupational commitment is notable when compared to the ones on organizational commitment. Both occupational and organizational commitment concepts are antecedents for critical organizational outcomes (Turner and Chelladurai, 2005). We chose to include an occupational commitment in our research model for several reasons. Given the HR trends highlighting the boost in a contingency in the workforce and reshaping in an understanding of career concept (such as career mosaics or 
portfolio careers), in case of a drawback regarding their work, employees not only reconsider their organizations but their occupations. Increasing numbers of people today change their occupations more frequently and perceive their career as an inter-occupational journey. Hence the concept of "commitment may be shifting from the organization to one's occupation" (Blau, 2003, p.469).

Another reason we chose occupational commitment instead of organizational commitment is the characteristics of our sample conveys. For teachers, the nature of the career differs from average employees as it is harder to change organizations when they have intention to quit. The majority of the teachers we responded for our surveys were working in public schools. This makes changing organizations (schools) even harder. An intention to quit has more possibility to result in a change in occupation and yield to high numbers of teachers changing their careers (Richardson and Watt, 2005). Attitudes towards the organization may yield to and even be perceived as attitudes towards the occupations. Chang (1999) provided evidence for the significant links between career commitment, turnover intention, and organizational commitment.

We extend on the above ideas to argue that occupational commitment may be a key determinant of organizational outcomes. There is numerous empirical evidence for significant spillover of employees' attitudes towards their organization on their attitudes toward their occupation and vice-versa (e.g. Klassen and Chiu, 2011; McCarthy, Lambert and Reiser, 2014). Occupational commitment can be an antecedent as well as an outcome of critical organizational variables. Goulet and Singh (2002) provided evidence for the significant associations between organizational commitment, job involvement, job satisfaction and occupational commitment. Occupational commitment predicts discretionary work behavior and overall job satisfaction stronger than organizational commitment (May, Korczynski and Frenkel, 2002). Knowledge inertia can be considered conceptually opposite to discretionary work behavior as the former manifests itself as being passive while the latter is about being active and self-initiated. This is consistent with our suggestion on the negative link between organizational commitment and knowledge inertia. Theoretical links between occupational commitment and behaviors indicating knowledge inertia may be found in the integrated model of commitment described by Meyer, Becker and Vandenberghe (2004). When 
employees lack occupational commitment, they do not have the need and motivation to invest their efforts in learning new things or trying innovative ways to enhance their skills and performance on that occupation. Instead, they have a tendency to do the minimum and keep up with the familiar. Building on these, we suggest a negative link between occupational commitment and knowledge inertia.

The positive association of intention to quit with organizational cynicism (Barnes, 2010) can be enlarged to occupational commitment (Klassen and Chiu, 2011). Employees who intend to leave their organizations are likely to decrease their involvement with the goals of the organization as well as the goals for their professional growth in that occupation. This in turn yields to inertia. Individuals who are not seeing themselves in the same career path for the future would decrease their involvement in their jobs, which would cause significant changes in their work-related behaviors. One of the most powerful motivators for most employees is progressing through their careers. If the motivation for climbing the ladders in the career journey is taken out of the equation, one of the most powerful sources for trying for the better also becomes excluded.

$\mathrm{H}_{2}$ : Occupational commitment has a significant and negative effect on knowledge inertia.

\section{Effects of Organizational Dissent on Knowledge Inertia}

Organizational dissent is about the expression of opposition and contradiction with the organization. Employees come across various practices or decisions of their organizations that they do not agree with. One possible reaction to those contradictions is to remain silent. Other is expressing the opposition actively or passively. Organizational dissent occurs when employees express their contradiction with the ideas, decisions, policies, or practices of the organization (Kassing, 1997, 2008). These expressions play an important role in criticizing, rethinking, and questioning the status quo and old methods that have been used. Hence, dissenting behaviors open doors for creativity and decrease inertia. Past research also provides evidence to support our suggestion on the link between organizational dissent and knowledge inertia. Employee voice yields to innovation while silence enhances conformity and lack of responsibility (Gambarotto and Cammozzo, 2010).

$\mathrm{H}_{3}$ : Organizational dissent has a significant and negative effect on 
knowledge inertia.

\section{Effects of Organizational Cynicism on Organizational Dissent and Occupational Commitment}

In their qualitative study, Mantere and Martinsuo (2001) present dissent as a form of expression of cynicism. In contrast, Naus, Iterson and Roe (2007) provided evidence for the distinctiveness of two concepts. Turgut and Arun (2016) provide evidence for the negative link between organizational cynicism and organizational dissent.

Individual factors, as well as organizational aspects, affect the nature and amount of dissent employees demonstrate (Kassing, 1997). How organizations value, reward or punish dissent is crucial to the emergence of dissenting behaviors. However, how employees perceive such outcomes and shape their expectations are up to the individual. The outcomes of organizational dissent change in accordance with to approach and reactions of the organization towards dissent. Organizational dissent can be utilized as a contribution to participative climate and employee identification with the organization (Kassing, 1997, p.311). It can also be observed as a counterproductive behavior (Kassing, 1997). Employees manage their behaviors in accordance with their perceptions of the expected reaction from the organization. Higher levels of organizational cynicism shape these perceptions and expectations in a pessimistic and skeptic way. Hence, employees experiencing higher levels of organizational cynicism demonstrate fewer dissenting behaviors.

Speaking up one's mind freely and confidently fundamentally necessitates high levels of trust. Employees need to be sure about the outcomes of their dissenting behavior will be positive and the organization will be sportive (Graham, 1986). Hence, by definition and with empirical evidence (e.g. Thompson, et al., 2000), individuals with higher levels of cynicism will have lower levels of trust for others and the organization and they will engage in less dissenting behavior. Research linking organizational silence with organizational cynicism (e.g. Nartgün and Kartal, 2013) supports our proposition for the link between organizational dissent and organizational cynicism.

The stream of research on organizational dissent is predominantly devoted to conceptually related constructs such as organizational silence and 
voice behavior. Organizational silence can be considered as an antithetically related construct with organizational dissent. Lack of organizational dissent is a form of describing organizational silence. Numerous studies addressing the link between organizational silence and organizational cynicism demonstrate a positive association between two concepts in the Turkish context (e.g. Erdoğdu, 2018; Karacaoğlu and Küçükköylü, 2015). Negative outcomes of organizational cynicism can act as another cause for a decreased level of organizational dissent. Avtgis, Thomas-Maddox, Taylor and Patterson (2007)'s findings demonstrating a negative link between burnout and organizational dissent are supportive of our proposition on organizational cynicism and organizational dissent.

No direct empirical evidence has been provided yet on the relationship between organizational cynicism and occupational commitment. Feldman (2000) suggests that cynicism changes the nature of a career in organizations as employees create psychological contracts for shorter terms. Employees who are skeptical and pessimistic about their organizations do not engage in long term plans.

Arora and Rangnekar (2015) provided evidence for the positive relationship between conscientiousness, agreeableness, and occupational commitment. The same personality dimensions were found to be negatively linked with organizational cynicism in a study conducted among teachers working in Turkey (Acaray and Y1ldırım, 2017).

$\mathrm{H}_{4}$ : Organizational cynicism has a significant and negative effect on organizational dissent.

$\mathrm{H}_{5}$ : Organizational cynicism has a significant and negative effect on occupational commitment.

\section{Indirect Effects of Organizational Cynicism on Knowledge Inertia}

There is empirical evidence for linking cynicism with decreased selfesteem (Fleming, 2005) which is an important ingredient for voice, career commitment, creativity, proactivity, and self-initiated change. Employees high on cynicism care less about the effects of their behaviors on others and the organization. They tend to have low levels of energy and dedication to speak their minds or invest in their occupations. This, in turn, yields to the negligence of new knowledge and methods in the organization. This is in line with the findings of Naus, Iterson and Roe (2007) which suggest a positive 
link between cynicism and neglect and a negative one with the voice.

The expectancy theory of motivation suggests that if individuals believe their efforts will not create an outcome they just stop trying. In line with the expectancy theory, employees keep their efforts and voices to themselves when they expect no positive change that will result from that form of dissent (Milliken, Morrison and Hewlin, 2003). Similarly, when employees are high on organizational cynicism, they create negative attitudes regarding distrust and pessimist expectations about how things will evolve in the organizations and their careers hence they are less likely to engage in dissenting behavior and invest in their careers. In turn, they will find no reason and energy for investing their efforts in scanning and adapting new methods or questioning the old ones.

Past research demonstrating that organizational cynicism results in increased levels of counterproductive work behavior, lower levels of organizational citizenship behavior and compliance (James, 2005) is supportive of our suggestions on the links between organizational cynicism, dissent, and knowledge inertia. In both cases, higher levels of cynicism yield to a picture where individuals comply with the status quo and standards and do not engage in extra-role behavior. Given the pattern of theoretical links and supportive evidence on the associations among variables of the study we hypothesize the following:

$\mathrm{H}_{6}$ : Organizational cynicism has a significant and positive indirect effect on knowledge inertia thorough decreased occupational commitment and organizational dissent.

\section{Research Model}

\section{Method}

This research aims to determine whether teachers' organizational cynicism affects their levels of knowledge inertia both directly and through organizational dissent and occupational commitment. Given the pattern of evidence in the literature and aforementioned theoretical underpinnings the research model of the study (Figure 1) depicts knowledge inertia as an antecedent of the organizational cynicism and addresses its direct effects and indirect effect through occupational commitment and organizational dissent on the concept.

For this purpose, we used the relational survey model. According to 
Salkind (2003), the relational survey model is proper for determining the variations among variables and the impact of the independent variable on the dependent variable. In order to test the proposed model and set the associations between study variables we utilized structural equation modeling, correlation and regression analysis. Structural equation models (SEM) test theoretical models that explain the relationships between variables $(\mathrm{Hu}$ and Bentler, 1998). Bootstrapping analysis was used to test the significance of indirect effects. We used confirmatory factor analysis and reliability analysis to test the fit and reliabilities of the scales.

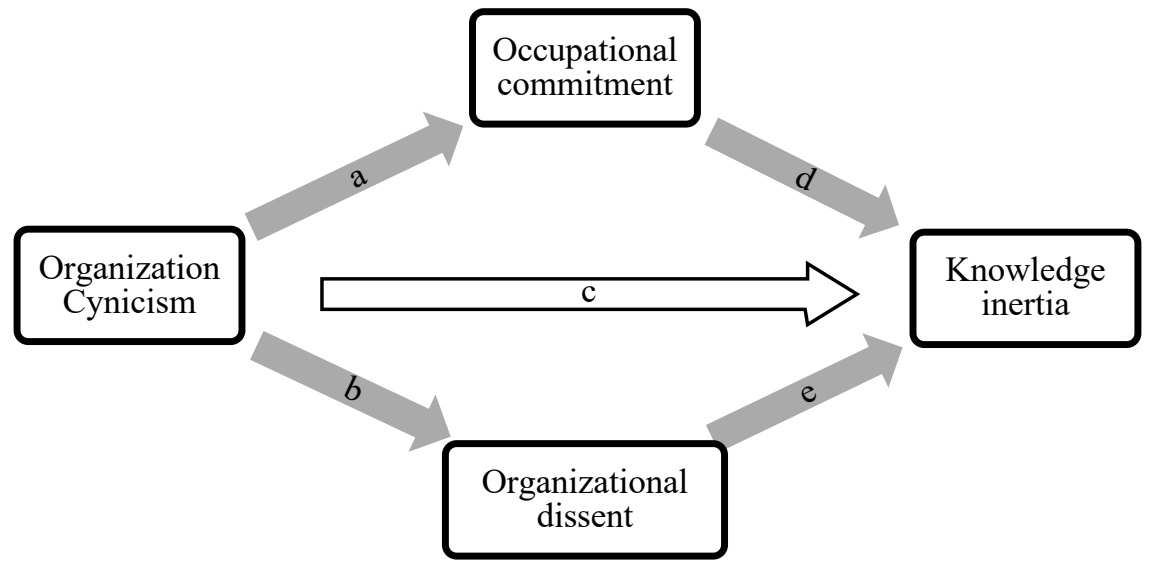

Figure 1. Research Model

\section{Population and Sample}

The study was conducted with 440 teachers working in public schools in Istanbul. Schermelleh-Engel, Moosbrugger and Müller (2003) stated that 400 or more samples were sufficient for maximum likelihood estimation method in structural equation modeling studies. Demographic information of the sample is given in Table 1.

The sample of this research consisted of 287 female teachers and 153 male teachers. Descriptive statistics depict that 91 of the teachers were 30 years old and younger (20.7\%), 173 of them were in the $31-40$ age range (39.3\%), 126 of them are in the 41-50 age range (28.6\%) and 50 of them are 51 years old and older. Approximately three-quarters of teachers had undergraduate education. Most teachers had seniority of 16-20 years. One hundred forty four $(32.7 \%)$ of the participating teachers work in primary schools, $214(48.6 \%)$ in secondary schools and $82(18.6 \%)$ in high schools. 
Table 1. Descriptive Statistics for the Sample

\begin{tabular}{llcc}
\hline Variable & Category & $\boldsymbol{f}$ & $\mathbf{\%}$ \\
\hline Gender & Female & 287 & 65.2 \\
& Male & 153 & 34.8 \\
\hline Age & 30 years and under & 91 & 20.7 \\
& 31-40 years & 173 & 39.3 \\
& 41-50 years & 126 & 28.6 \\
& 51 years and older & 50 & 11.4 \\
\hline Education & Undergraduate & 382 & 86.8 \\
& Postgraduate & 58 & 13.2 \\
\hline Professional & 5 years and under & 75 & 17.0 \\
seniority & 6-10 years & 77 & 17.5 \\
& 11-15 years & 99 & 22.5 \\
& 16-20 years & 103 & 23.4 \\
& 21 years and above & 86 & 19.5 \\
\hline Tenured school & Primary school & 144 & 32.7 \\
level & Middle School & 214 & 48.6 \\
& High school & 82 & 18.6 \\
\hline
\end{tabular}

\section{Data Collection Tools}

In order to collect data in the study, the necessary permission was obtained from the Ethics Committee of Istanbul Sabahattin Zaim University (dated 27.03.2020 and numbered 2020/03).

\section{Organizational Cynicism Scale}

The Organizational Cynicism Scale was developed by Brandes (1997) and updated by Brandes, Dharwadkar and Dean (1999) in order to determine the negative attitudes of the participants towards their organization. The scale was adapted to Turkish by Kalağan (2009). Organizational cynicism scale measures three dimensions: cognitive, affective, and behavioral, and consists of 13 items. Kasalak and Aksu (2014) calculated high (.86-.94) reliability coefficients for the entire scale and its sub-dimensions.

\section{Occupational Commitment Scale}

The Occupational Commitment Scale (OCB), developed by Blau (2003), is a 24-item measurement tool that evaluates the commitment developed by individuals for their professions in four different dimensions: emotional commitment, normative commitment, accumulated costs and limitation of alternatives. Utkan and Kırdök (2018) adapted scale to Turkish. In the scale, only four items in the sub-dimension of the limitation of alternatives $(19,20,21,22)$ are reverse scored. High scores obtained from the scale indicates high occupational commitment. Utkan and Kırdök (2018) 
provided high reliability scores for the scale and the subscales ranging between .83-.95.

\section{Organizational Dissent Scale}

The 24-item Organizational Dissent Scale developed by Kassing (1998) consists of three dimensions: displaced dissent, latent dissent and articulated dissent. The scale was adapted to Turkish by Ergün and Çelik (2018) and items $1,4,13,14,15,18$ and 20 were excluded from the process of adaptation analyzes. Items 2, 3, 4, 6, 8, 10 and 14 are reverse scored. Ergün and Çelik (2018) reported high Cronbach Alpha scores for the dimensions of the scale ranging from .959 to 969 .

\section{Knowledge Inertia Scale}

The scale was developed by Liao, Fei, and Liu, (2008) and adapted to Turkish by Çankaya (2010). The scale consists of 14 items and 2 subscales: Learning inertia and Experience inertia. Items 1, 6 and 8 are reverse scored. Çankaya (2010) calculated high reliability scores for the subscales $(.70$ and $.84)$.

\section{Analysis of Data}

First, means, standard deviations, kurtosis and skewness values and reliability coefficients for normality of the variables were calculated

Table 2. Descriptive Statistics for the Scales Used in the Study

\begin{tabular}{lccccc}
\hline & M & SD & Skewness & Kurtosis & $\begin{array}{c}\text { Cronbach } \\
\text { Alpha }(\boldsymbol{\alpha})\end{array}$ \\
\hline 1. Knowledge Inertia & 2.585 & .405 & -.300 & -.424 & .607 \\
2. Organizational Dissent & 3.161 & .349 & .356 & -.277 & .709 \\
3. Organization Cynicism & 1.961 & .611 & .200 & -.700 & .901 \\
4. Occupational Commitment & 3.535 & .626 & -.003 & -.380 & .886 \\
\hline
\end{tabular}

The scales indicated adequate and high reliabilities and the data showed normal distribution. A mediation test was used to test the research model. The mediation test, one of the structural equation models (SEM), was used to test the hypothesis of the research model. AMOS 25 was used to run the analysis. The mediating roles of the variables can be analyzed through various methods. In this research, the mediation model of Baron and Kenny (1986) was used. Three conditions are proposed for mediation testing: "In order to perform mediation test, (i) independent variable must affect dependent and mediator variable; (ii) the mediating variable must affect the dependent variable. (iii) 
When the independent variable and the mediator variable are included in the analysis, the effect of the independent variable on the dependent variable must be " 0 " zero or decrease." The mediator variable can be said to be strong when it approaches zero or if there is a significant decrease (Baron and Kenny, 1986). In order to fulfill the conditions of the mediation test, the relationships between the mediator and dependent variables of the independent variable and the effect of the independent variable on the mediator and dependent variables were calculated, respectively.

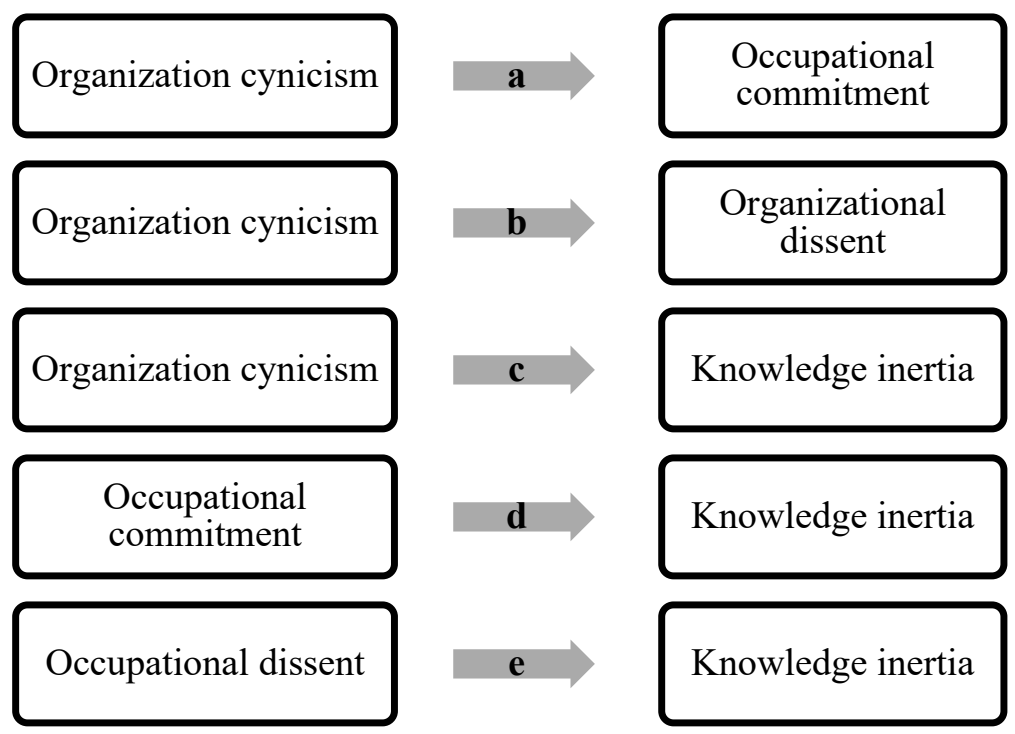

Figure 2. Analysis Stages of the Model

When analyzing the data, the steps given in Figure 2 were followed. The effect of organizational cynicism on occupational commitment (path a), organizational dissent (path b) and knowledge inertia (path c); the effect of occupational commitment on knowledge inertia (path d); The effect of organizational dissent on knowledge inertia (path e) was determined. Finally, the mediation role of occupational commitment and organizational dissent was tested in the relationship between organizational cynicism and knowledge inertia given in research model (Figure 1).

According to the research model of the study, organizational cynicism influences knowledge inertia both directly and indirectly through occupational commitment and organizational dissent. Chi square $\left(\chi^{2}\right)$, df (Degrees of freedom), $\chi^{2} / \mathrm{df}$ ratio, GFI (Goodness-of-fit index), AGFI (Adjusted) 
Goodness-of-fit index, TLI (Tucker-Lewis index), RMR (Root mean square residuals), SRMR (Standardized root mean square residual), NFI (Normed fit index), CFI (Comparative fit index), RMSEA (Root mean square error of approximation) values are recommended to be examined (Hu and Bentler, 1999; Jöreskog, 2004). The research model was assessed according to the fit indices given in Table 3.

Tablo 3. Fit Indexes for Proposed Models in the Study

\begin{tabular}{lll}
\hline Index of fit & Perfect Fit & Adequate Fit \\
\hline$\chi^{2}$ & $0 \leq \chi^{2} \leq 3$ & $3 \leq \chi^{2} \leq 5$ \\
\hline $\mathrm{df}$ & Degree of freedom & \\
\hline$p$ & $p<.01$ & $p<.05$ \\
\hline$\chi^{2} / \mathrm{df}$ & $0 \leq \chi^{2} / \mathrm{df} \leq 3$ & $3 \leq \chi^{2} / \mathrm{df} \leq 5$ \\
\hline RMR & $0<\mathrm{RMR} \leq 0.5$ & $0,5<\mathrm{RMR}<1$ \\
\hline SRMR & $0<\mathrm{SRMR} \leq 0.5$ & $0.5<\mathrm{SRMR} \leq 0.8$ \\
\hline GFI & $0.95 \leq \mathrm{GFI} \leq 1.00$ & $0.90 \leq \mathrm{GFI} \leq 0.95$ \\
\hline AGFI & $0.90 \leq \mathrm{AGFI} \leq 1.00$ & $0.85 \leq \mathrm{AGFI} \leq 0.90$ \\
\hline NFI & $0.95 \leq \mathrm{NFI} \leq 1.00$ & $0.90 \leq \mathrm{NFI} \leq 0.95$ \\
\hline TLI & $0.95 \leq \mathrm{TLI} \leq 1.00$ & $0.90 \leq \mathrm{TLI} \leq 0.95$ \\
\hline CFI & $0.95 \leq \mathrm{CFI} \leq 1.00$ & $0.90 \leq \mathrm{CFI} \leq 0.95$ \\
\hline RMSEA & $0 \leq \mathrm{RMSEA} \leq 0.05$ & $0.05 \leq \mathrm{RMSEA} \leq 0.08$
\end{tabular}

Source: Bentler and Bonett (1980); Byrne, Shavelson and Muthen (1989); Hu and Bentler (1999); Kline (2011); Maydeu-Olivares and Garc1'a-Forero (2010); Schermelleh-Engel, Moosbrugger and Müller (2003); Schumacker and Lomax (2010); Tabachnick and Fidell (2007).

\section{Results}

In order to test the theoretical model, the correlation coefficients between the variables were calculated.

Table 4. Means, Standard Deviations, and Correlations among the Study Variables

\begin{tabular}{lcccccc}
\hline & M & SD & $\mathbf{1}$ & $\mathbf{2}$ & $\mathbf{3}$ & $\mathbf{4}$ \\
\hline 1. Knowledge Inertia & 2.585 & .405 & 1 & & & \\
2. Organizational Dissent & 3.161 & .349 & $-.320^{* *}$ & 1 & & \\
3. Organization Cynicism & 1.961 & .611 & $.266^{* *}$ & $-.095^{*}$ & 1 & \\
4. Occupational Commitments & 3.535 & .626 & $-.305^{* *}$ & .074 & $-.307^{* *}$ & 1 \\
\hline${ }^{p}<.05, p<.01, \mathrm{~N}=440$ & & & & & &
\end{tabular}

Table 4 depicts that there are moderate and negative relationships between knowledge inertia and organizational dissent $(\mathrm{r}=-.320 ; p<.01)$ and occupational commitment $(\mathrm{r}=-.305 ; p<.01)$, and there is a positive relationship between knowledge inertia and organizational cynicism $(\mathrm{r}=.266 ; p<.01)$. While there is a negative relationship between organizational cynicism and 
organizational dissent $(\mathrm{r}=-.095 ; p<.05)$, there is no significant relationship between organizational dissent and occupational commitment $(\mathrm{r}=.074$; $p>.05)$. Findings revealed that there is a negative relationship between organizational cynicism and occupational commitment $(\mathrm{r}=-.307)$. In other words, the results of the correlation analysis produced supportive evidence for the proposed model. Primarily, the effect of organizational cynicism on knowledge inertia was calculated.

Organization Cynicism

\section{$\mathrm{d}=.27 ; p<.01$}

\section{Knowledge inertia}

Figure 3. The Effect of Organizational Cynicism on Knowledge Inertia

Figure 3 shows that organizational cynicism significantly affects knowledge inertia. Organizational dissent and occupational commitment variables were added to the model as mediator variables and the model was tested again.

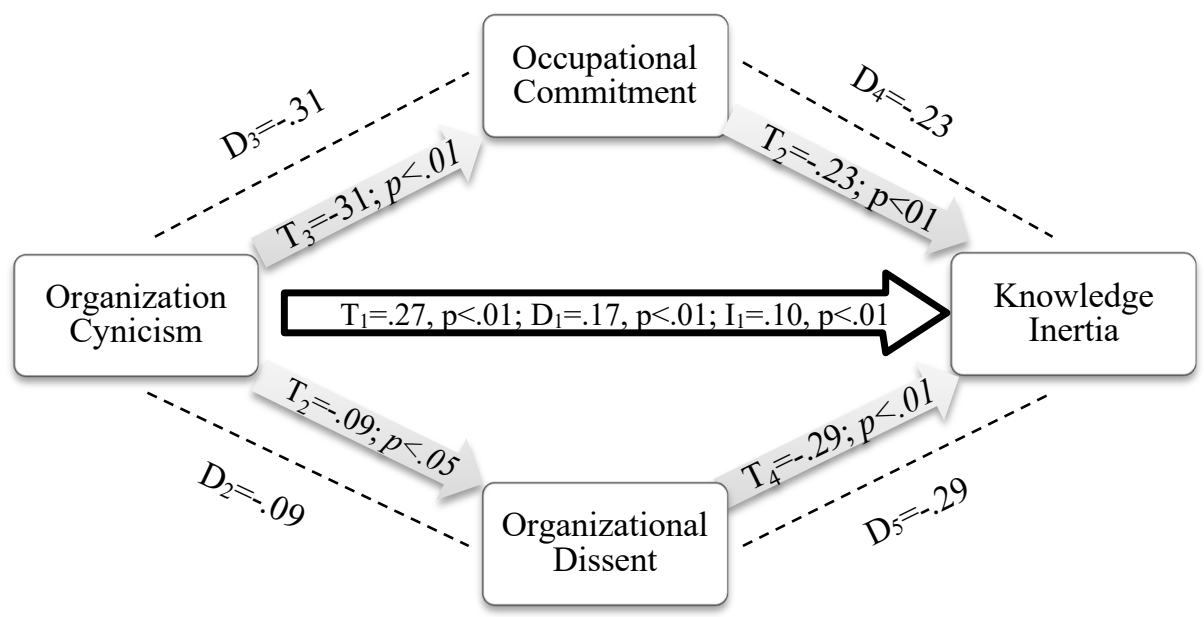

${ }^{*} p<.05,{ }^{* *} p<.01$. (2-tailed). T: Total effect; D: Direct effect, I: Indirect effect

Figure 4. Model with Organization Cynicism as the Independent Variable

Figure 4 shows that organizational cynicism affects knowledge inertia both directly $(\beta=.17 ; p<.01)$ and indirectly $(\beta=.10 ; p<.01)$ through organizational dissent and occupational commitment (total effect, $\beta=.27$; $p<.01)$. Organizational cynicism also has a significant direct effect on organizational dissent $(\beta=-.09 ; p<01)$ and occupational commitment $(\beta=-.31$; $p<.01)$. Organizational dissent has a significant direct effect $(\beta=-.29 ; p>.01)$ on knowledge inertia. Occupational commitment has a significant direct effect 
$(\beta=-.23 ; p<.01)$ on knowledge inertia. Further, results indicate that occupational commitment and organizational dissent are partial mediators in the relationship between organizational cynicism and knowledge inertia, and organizational cynicism has a significant indirect effect on knowledge inertia through organizational dissent and occupational commitment. Results of bootstrapping analysis indicate a significant indirect effect (point estimate $=0.1, p<0.01)$. Values regarding the total, direct and indirect effects among the variables are given in Table 5.

Table 5. Direct, Indirect and Total Effects between variables

\begin{tabular}{lccc}
\hline Organizational cynicism --> knowledge inertia & $\begin{array}{c}\text { Total } \\
\text { Effect }\end{array}$ & $\begin{array}{c}\text { Direct } \\
\text { Effect }\end{array}$ & $\begin{array}{c}\text { Indirect } \\
\text { Effect }\end{array}$ \\
\hline Organizational cynicism --> organizational dissent & -.266 & .168 & .099 \\
\hline Organizational cynicism --> occupational commitment & -.307 & -.095 & .000 \\
\hline Organizational dissent --> knowledge inertia & -.288 & -.288 & .000 \\
\hline Occupational commitment --> knowledge inertia & -.233 & -.233 & .000 \\
\hline
\end{tabular}

In order to evaluate the model, the fit indices (Table 6) were examined.

Table 6. Fit Indexes for Proposed Models in the Study

\begin{tabular}{|c|c|c|c|c|c|c|c|c|c|c|c|}
\hline & $\chi^{2}$ & $d f$ & $p$ & $\chi^{2} / d f$ & RMR & SRMR & GFI & AGFI & TLI & CFI & RMSEA \\
\hline Model & .996 & 1 & .318 & .996 & .003 & .015 & .999 & .989 & .1 .00 & 1.0 & .000 \\
\hline Values & 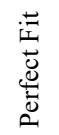 & 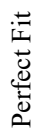 & $\begin{array}{l}\text { 志 } \\
\text { 苞 } \\
\stackrel{0}{0} \\
0\end{array}$ & 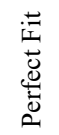 & $\begin{array}{l}\text { 茞 } \\
\text { 芯 } \\
\text { 范 }\end{array}$ & 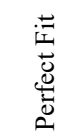 & 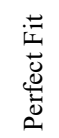 & 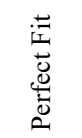 & 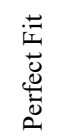 & 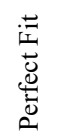 & 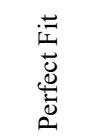 \\
\hline
\end{tabular}

$\chi^{2}=$ Chi-square; $\mathrm{df}=$ degree of freedom; $p<.05 ; \mathrm{RMR}=$ Root mean square residuals; SRMR=Standardized root mean square residual; GFI=Goodness-of-fit index; AGFI=Adjusted goodness-of-fit index; TLI=Turker-Lewis Index; $\mathrm{CFI}=$ Comparative Fit Index; RMSEA=Root mean square error of approximation.

Fit indexes of the tested theoretical model confirm the validity of the model. However, the results of the regression analysis regarding the prediction of knowledge inertia through organizational cynicism, organizational dissent and occupational commitment are given in Table 7.

Table 7. Regression Analysis Regarding the Prediction of Knowledge Inertia

\begin{tabular}{llccccc}
\hline Independent Variables & $\begin{array}{l}\text { Dependent } \\
\text { Variable }\end{array}$ & $\mathbf{B}$ & $\begin{array}{c}\text { Std. } \\
\text { Error. }\end{array}$ & $\mathbf{( \beta )}$ & $\mathbf{t}$ & $\boldsymbol{p}$ \\
\hline Constant & & 3949 & .206 & & 19.168 & .000 \\
Organization Cynicism & Knowledge & .111 & .030 & .167 & 3.721 & .000 \\
Organizational Dissent & Inertia & -.332 & .050 & -.287 & -6.683 & .000 \\
Occupational Commitment & & -.150 & .029 & -.232 & -5.173 & .000 \\
\hline
\end{tabular}

$\mathrm{R}=.455 ; \mathrm{R}^{2}=.207 ; \mathrm{F}=37.879 ; p<.000$ 
Findings depicted on Table 6 demonstrate that organizational cynicism and organizational dissent and occupational commitment significantly predict knowledge inertia $\left(\mathrm{R}=.455 ; \mathrm{R}^{2}=.207 ; \mathrm{F}=37.879 ; p<.000\right)$. Organizational cynicism and organizational dissent and occupational commitment together explain $21 \%$ of the total variance in knowledge inertia. While organizational cynicism affects knowledge inertia positively, organizational dissent and occupational commitment affect negatively. While organizational cynicism increases knowledge inertia, it reduces organizational dissent and occupational commitment.

\section{Discussion}

Inertia, specifically knowledge inertia, increasingly becomes a center of attention with the efforts for adaptability, flexibility and agility that the rapid change, current trends and dynamics demand. Practitioners as well as academicians realize the importance of the concept and necessity for understanding the antecedents and mechanisms how those antecedents work for creating or avoiding inertia. Given the scarcity of the research addressing this necessity, current study suggests organizational cynicism, occupational commitment and organizational dissent as antecedents for knowledge inertia. Specifically, study tests the mediation role of occupational commitment and organizational dissent in the relationship between organizational cynicism and knowledge inertia. We suggest that through decreasing occupational commitment and dissenting behavior, organizational cynicism increase knowledge inertia.

Findings from path analysis support the hypothesis of the research as they demonstrate that organizational cynicism has a significant positive direct effect of on knowledge inertia. Occupational commitment and organizational dissent also affect knowledge inertia significantly. A partial mediation is validated as findings of bootstrapping analysis indicate significant indirect effects of organizational cynicism on knowledge inertia through occupational commitment and organizational dissent.

The scarcity of the studies addressing the variables of the research model directly makes it difficult to compare our findings with other findings in the literature. Thus, we used conceptually relevant, similar or opposite concepts to support our hypothesis and results. Our findings are in line with Farjam et al. (2018)'s findings associating organizational cynicism, occupational burnout and organizational silence significantly. Findings 
depicting a negative association between organizational cynicism and change commitment (Bernerth, Armenakis, Feild and Walker, 2007) and a negative one with organizational citizenship behavior (Andersson and Bateman; 1997) and organizational learning (Schilling and Kluge, 2009) are consistent with our findings linking organizational cynicism and knowledge inertia positively. Naus, Iterson and Roe (2007)'s findings suggesting a negative link between voice behavior and cynicism and a positive one with neglect and cynicism are coherent with our results.

Findings of the study provide valuable information and suggestions for practitioners and researchers. To cope with knowledge inertia in the organizations, leaders should consider organizational cynicism as an important antecedent and understand the mechanisms that may link the concepts. Human resources management practices and leadership efforts enhancing the occupational commitment and organizational dissent can be adapted for mitigating knowledge inertia. Theory and meta analysis on the antecedent of cynicism include employees' perceptions on organizational justice and organizational support (Chiaburu et al., 2013). Management practices enhancing such dynamics that are built on the awareness that cynicism decrease occupational commitment and organizational dissent and increase knowledge inertia can yield to higher innovation and participation to decision making.

The study contributes to existing knowledge on the knowledge inertia by providing information and evidence on the antecedents and possible mediating mechanisms for knowledge inertia. Readers should acknowledge that the sample of this study consist of teachers and school environments that provide a unique climate for knowledge inertia and its antecedents. Research on other contexts may better test the generalizability of the findings for other organizations. Further research on other possible mediator or moderator variables may help to better elucidate the organizational and individuals' mechanisms through which cynicism affects knowledge inertia.

In order to collect data in the study, the necessary permission was obtained from the Ethics Committee of Istanbul Sabahattin Zaim University (dated 27.03.2020 and numbered 2020/03). 


\section{References}

Acaray, A. and Yildırım, S. (2017). The impact of personality traits on organizational cynicism in the education sector. World Journal of Entrepreneurship, Management and Sustainable Development, 13(1), 65-76.

Andersson, L. M. (1996). Employee cynicism: An examination using a contract violation framework. Human Relations, 49(11), 1395-1418.

Andersson, L. M. and Bateman, T. S. (1997). Cynicism in the workplace: Some causes and effects. Journal of Organizational Behavior, 18, 449-469.

Arora, R. and Rangnekar, S. (2015). The joint effects of personality and supervisory career mentoring in predicting occupational commitment. Career Development International, 20(1), 63-80.

Avtgis, T. A., Thomas-Maddox, C., Taylor, E. and Patterson, B. R. (2007). The influence of employee burnout syndrome on the expression of organizational dissent. Communication Research Reports, 24(2), 97-102.

Barnes, L. L. (2010). The effects of organizational cynicism on community colleges: Exploring concepts from positive psychology. Unpublished doctoral dissertation, Claremont Graduate University, Claremont.

Baron, R. M. and Kenny, D. A. (1986). The Moderator-mediator variable distinction in social psychological research: Conceptual, strategic, and statistical considerations. Journal of Personality and Social Psychology, 51, 1173-1182.

Bentler, P. M. and Bonett, D. G. (1980). Significance tests and goodness of fit in the analysis of covariance structures. Psychological Bulletin, 88(3), 588-606.

Bernerth, J. B., Armenakis, A. A., Feild, H. S. and Walker, H. J. (2007). Justice, cynicism, and commitment: A study of important organizational change variables. The Journal of Applied Behavioral Science, 43(3), 303-326.

Blau, G. (2003). Testing for a four-dimensional structure of occupational commitment. Journal of occupational and organizational psychology, 76(4), 469-488.

Blau, G. J. (1985). The measurement and prediction of career commitment. Journal of occupational Psychology, 58(4), 277-288.

Boyer, M. and Robert, J. (2006). Organizational inertia and dynamic incentives. Journal of Economic Behavior \& Organization, 59(3), 324-348.

Brandes, P. (1997). Organizational cynicism: Its nature, antecedents, and consequences. Doctoral dissertation, University of Cincinati, Available from ProOuest Dissertations and Theses database. UMI No. 9814494

Brandes, P., Dharwadkar, R. and Dean, J. W. (1999). Does organizational cynicism matter? Employee and supervisor perspectives on work outcomes. Eastern Academy of Management Proceedings, 2(1), 150-153. Outstanding Empirical Paper Award.

Byrne, B. M., Shavelson, R. J. and Muthen, B. (1989). Testing for the equivalence of factor covariance and mean structures: The issue of partial measurement in variance. Psychological Bulletin, 105, 456-466.

Chang, E. (1999). Career commitment as a complex moderator of organizational commitment and turnover intention. Human Relations, 52(10), 1257-1278.

Chang, H. T., Chi, N. W. and Miao, M. C. (2007). Testing the relationship between three-component organizational/occupational commitment and organizational/occupational turnover intention using a non-recursive model. Journal of Vocational Behavior, 70(2), 352-368. 
Cheng, T. and Lin, C. (2011). A study on relationships between teacher's knowledge inertia, school organizational learning and school effectiveness in elementary schools. Teacher education and education organization reform seminar in primary and secondary schools across the Taiwan Strait, 217-240.

Chiaburu, D. S., Peng, A. C., Oh, I. S., Banks, G. C. and Lomeli, L. C. (2013). Antecedents and consequences of employee organizational cynicism: A meta-analysis. Journal of Vocational Behavior, 83(2), 181-197.

Çankaya, İ. H. (2010). İlköğretim okul yöneticilerinin vicdan odaklı yaklaşım düzeyleri ile atalet algıları arasındaki ilişki. Ahi Evran Üniversitesi Kırşehir Eğitim Fakültesi Dergisi, 11(2), 65-74.

Dean, J. W., Brandes, P. and Dharwadkar, R. (1998). Organizational cynicism. Academy of Management Review, 23(2), 341-352.

Ekvall, G. and Tångeberg-Andersson Y. (1986). Working climate and creativity: A study of an innovative newspaper office. The Journal of Creative Behavior, 20, 215-225.

Doi: $10.1002 /$ j.2162-6057.1986.tb00438

Erdoğdu, M. (2018). Effect of organizational justice behaviors on organizational silence and cynicism: A research on academics from schools of physical education and sports. Universal Journal of Educational Research, 6(4), 733-741.

Ergün, H. and Çelik, K. (2018). Örgütsel Muhalefet Ölçeği Türkçe uyarlamas1. Mehmet Akif Ersoy Üniversitesi Ë̆itim Fakültesi Dergisi, 48, 398-414.

Farjam, S., Almodarresi, S. M. A., Pirvali, E., Saberi, H. and Malekpour, S. (2018). The mediator effect of occupational burnout on the relationship between organizational cynicism and organizational silence (Case of study: employees of Farokhshahr social security organization hospital). Revista Publicando, 5(15), 1136-1159.

Feldman, D. C. (2000). The Dilbert syndrome: How employee cynicism about ineffective management is changing the nature of careers in organizations. American Behavioral Scientist, 43(8), 1286-1300.

Fleming, P. (2005). Workers' playtime? Boundaries and cynicism in a "Culture of Fun” program. The Journal of Applied Behavioral Science, 41(3), 285-303.

Gambarotto, F. and Cammozzo, A. (2010). Dreams of silence: Employee voice and innovation in a public sector community of practice. Innovation, 12(2), 166179.

Gong, Y., Cheung, S. Y., Wang, M. and Huang, J. C. (2012). Unfolding the proactive process for creativity: Integration of the employee proactivity, information exchange, and psychological safety perspectives. Journal of Management, 38(5), 1611-1633.

Goulet, L. R. and Singh, P. (2002). Career commitment: a reexamination and an extention. Journal of Vocational Behavior, 61, 73-91.

Graham, J. W. (1986). Principled organizational dissent: a theoretical essay. Research in Organizational Behavior, 8, 1-52.

Gray, D. M., D'Alessandro, S., Johnson, L. W. and Carter, L. (2017). Inertia in services: causes and consequences for switching. Journal of Services Marketing, 31(6), 485-498.

Hedberg, B. L. T. and Wolff, R. (2003). Organizing, learning, and strategizing: from construction to discovery. In Dierkes, M., Berthoin Antal, A., Child, J. and 
Nonaka, I., (Eds.), Handbook of organizational learning and knowledge (pp. 535-556). New York: Oxford University Press.

Hu, L. and Bentler, P. M. (1998). Fit indices in covariance structure modeling: Sensitivity to underparameterized model misspecification. Psychological Methods, 3(4), 424-453.

Hu, L. and Bentler, P. M. (1999). Cutoff criteria for fit indexes in covariance structure analysis: Conventional criteria versus new alternatives. Structural Equation Modeling, 6(1), 1-55.

James, M. S. (2005). Antecedents and consequences of cynicism in organizations: An examination of the potential positive and negative effects on school systems. Unpublished doctoral dissertation, The Florida State University, Florida.

Joo, B. K., Yang, B. and McLean, G. N. (2014). Employee creativity: The effects of perceived learning culture, leader-member exchange quality, job autonomy, and proactivity. Human Resource Development International, 17(3), 297-317.

Jöreskog, K. G. (2004). On chi-squares for the independence model and fit measures in Lisrel.

http://www.ssicentral.com/lisrel/techdocs/ftb.pdf

Kafchehi, P., Zamani, A. and Ebrahimabadi, F. (2012). A model of influential factors on knowledge inertia. Asian Journal of Business Management, 4(4), 386-391.

Kalağan, G. (2009). Araştırma görevlilerinin örgütsel destek alglları ile örgütsel sinizm tutumları arasındaki ilişki. Unpublished masters thesis, Akdeniz Üniversitesi, Sosyal Bilimler Enstitüsü.

Karacaoğlu, K. and Küçükköylü, C. (2015). İşgören sessizliğinin örgütsel sinizme etkisi: kamu çalışanları üzerine bir araştırma. Ege Akademik Bakış, 15(3), 401408.

Kasalak, G. and Aksu, M. B. (2014). Araştırma görevlilerinin algıladıkları örgütsel desteğin örgütsel sinizm ile ilişkisi. Kuram ve Uygulamada Eğitim Bilimleri, 14(1), 115-133.

Kassing, J. W. (1997). Articulating, antagonizing, and displacing: A model of employee dissent. Communication Studies, 48(4), 311-332.

Kassing, J. W. (1998). Development and validation of the organizational dissent scale. Management Communication Quarterly, 12(2), 183-229.

Kassing, J. W. (2008). Dissent in organizations. In W. Donsbach, (Ed.), The international encyclopedia of communication. New Jersey: John Wiley \& Sons.

Doi:10.1002/9781405186407.wbiecd056

Klassen, R. M. and Chiu, M. M. (2011). The occupational commitment and intention to quit of practicing and pre-service teachers: Influence of self-efficacy, job stress, and teaching context. Contemporary Educational Psychology, 36(2), 114-129.

Kline, R. B. (2011). Principles and practice of structural equation modeling. New York: The Guilford Press.

Lee, K., Carswell, J. J. and Allen, N. J. (2000). A meta-analytic review of occupational commitment: relations with person-and work-related variables. Journal of Applied Psychology, 85(5), 799-811

Liao, S. H. (2002). Problem solving and knowledge inertia. Expert Systems with Applications, 22(1), 21-31. 
Liao, S. H., Fei, W. C. and Liu, C. T. (2008). Relationships between knowledge inertia, organizational learning and organization innovation. Technovation, 28(4), 183-195.

Mantere, S. and Martinsuo, M. (2001). Adopting and questioning strategy: Exploring the roles of cynicism and dissent. In $17^{\text {th }}$ EGOS-European Group for Organizational Studies Colloquium. July 5-7, Lyon, France, 1-25.

May, T. Y. M., Korczynski, M. and Frenkel, S. J. (2002). Organizational and occupational commitment: Knowledge workers in large corporations. Journal of Management Studies, 39(6), 775-801.

Maydeu-Olivares, A. and Garcia Forero, C. (2010). Goodness-of-fit testing. International Encyclopedia of Education, 7, 190-196.

McCarthy, C. J., Lambert, R. G. and Reiser, J. (2014). Vocational concerns of elementary teachers: Stress, job satisfaction, and occupational commitment. Journal of Employment Counseling, 51(2), 59-74.

McGregor, D. (1960). The human side of enterprise. New York: McGraw-Hill.

Meyer, J. P. and Allen, N. J. (1991). A three-component conceptualization of organizational commitment. Human Resource Management Review, 1(1), 61-89.

Meyer, J. P., Allen, N. J. and Smith, C. A. (1993). Commitment to organizations and occupations: Extension and test of a three-component conceptualization. Journal of Applied Psychology, 78(4), 538-551.

Meyer, J. P., Becker, T. E. and Vandenberghe, C. (2004). Employee commitment and motivation: a conceptual analysis and integrative model. Journal of Applied Psychology, 89(6), 991-1007.

Milliken, F. J., Morrison, E. W. and Hewlin, P. F. (2003). An exploratory study of employee silence: Issues that employees don't communicate upward and why. Journal of Management Studies, 40, 1453-1476.

Mokyr, J. (2000). Innovation and its enemies: the economic and political roots of technological inertia. In M. Olson and S. Kähkönen, (Eds.), A not-so-dismal science: a broader view of economics (pp. 61-91). New York: Oxford University Press.

Nartgün, S. S. and Kartal, V. (2013). Ögretmenlerin örgütsel sinizm ve örgütsel sessizlik hakkindaki görüşleri. Bartın Üniversitesi Eğitim Fakültesi Dergisi, 2(2), 47-67.

Naus, F., Van Iterson, A. and Roe, R. (2007). Organizational cynicism: Extending the exit, voice, loyalty, and neglect model of employees' responses to adverse conditions in the workplace. Human Relations, 60(5), 683-718.

Richardson, P. W. and Watt, H. M. G. (2005). 'I've decided to become a teacher': Influences on career change. Teacher and Teacher Education, 21, 475-489.

Salkind, N. J. (2003). Exploring research. Upper Saddle River, NJ: Prentice Hall.

Schermelleh-Engel, K., Moosbrugger, H. and Müller, H. (2003). Evaluating the fit of structural equation models: tests of significance and descriptive goodness-offit measures. Methods of Psychological Research Online, 8(2), 23-74.

Schilling, J. and Kluge, A. (2009). Barriers to organizational learning: An integration of theory and research. International Journal of Management Reviews, 11(3), 337-360.

Schumacker, R. E. and Lomax, R. G. (2010). A beginner's guide to structural equation modeling. New York: Routledge Taylor \& Francis Group. 
Stanley, D. J., Meyer, J. P. and Topolnytsky, L. (2005). Employee cynicism and resistance to organizational change. Journal of Business \& Psychology, 19(4), 429-459.

Tabachnick, B. G. and Fidell, L. S. (2007). Using multivariate statistics (5 ${ }^{\text {th }}$ ed.). Boston: Allyn and Bacon.

Thompson, R. C., Joseph, K. M., Bailey, L. L., Worley, J. A. and Williams, C. A. (2000). Organizational change: An assessment of trust and cynicism (No. DOT/FAA/AM-00/14). Civil Aeromedical Institute. the National Technical Information Service, Springfield, Virginia. https://rosap.ntl.bts.gov/view/dot/21487.

Turgut, T. and Agun, H. (2016). The relationship between organizational justice and organizational cynicism: The mediating role of psychological capital and employee voice. Işs'te Davranış Dergisi, 1(1), 15-26.

Turner, B. A. and Chelladurai, P. (2005). Organizational and occupational commitment, intention to leave, and perceived performance of intercollegiate coaches. Journal of Sport Management, 19(2), 193-211.

Utkan, Ç. and Kırdök, O. (2018), Dört Boyutlu Mesleki Bağlılık Ölçeği uyarlama çalışması. International Journal of Social Sciences and Education Research, 4(2), 230-244.

Doi: 10.24289/ijsser.407961.

Zhang, Q., Sun, S., Zheng, X.and Liu, W. (2019). The role of cynicism and personal traits in the organizational political climate and sustainable creativity. Sustainability, 11(1), 257-274.

Zhao, W. D., Wu, J. H. and Wang, Y. (2012). The moderating effect of knowledge inertia on the relationship between organizational learning and employee-organization fit. Journal of Industrial Engineering and Engineering Management, 7-14 